This is the version of the article accepted for publication in Human Resource Management published by Wiley: https://onlinelibrary.wiley.com/journal/1099050x\#pane-01cbe741-499a-4611-874e-1061f1f4679e01

Accepted version downloaded from SOAS Research Online: http://eprints.soas.ac.uk/30420

\title{
IS CO-WORKER FEEDBACK MORE IMPORTANT THAN SUPERVISOR FEEDBACK FOR INCREASING INNOVATIVE BEHAVIOR?
}

\author{
(Accepted Version)
}

Authors: Nathan Eva, Hannah Meacham, Alexander Newman, Gary Schwarz \& Tse Leng Tham

Journal: Human Resource Management (2019)

\begin{abstract}
A growing body of research explores human resource management practices that encourage employees to innovate. In this study, we examine the links between different sources of feedback (supervisor and co-worker) and employees' innovative behavior. Drawing on social exchange theory and the job demands-resources theory, we first propose that work engagement and psychological contract breach mediate the relationship between supervisor feedback and employees' innovative behavior. Second, we propose a moderated-mediation model in which coworker feedback attenuates the relationships between supervisor feedback and employees' innovative behavior through the mediating mechanisms of both work engagement and psychological contract breach. Using three waves of multi-source data from 300 Chinese employees and their 64 supervisors, we found a dual-mediation pathway by which employees' work engagement and perceptions of psychological contract breach mediate the influence of supervisor feedback on innovative behavior. Our results also show that co-worker feedback can be used to supplement the lack of supervisor feedback when required. Organizations are advised to ensure that employees obtain regular feedback from multiple sources because such feedback can promote employees' work engagement and perceptions that the organization is upholding its side of the psychological contract, which fosters employees' innovative behavior.
\end{abstract}

Keywords: Co-worker feedback; innovative behavior; psychological contract breach; supervisor feedback; work engagement. 


\section{INTRODUCTION}

Promoting innovative behavior has become imperative for organizations aiming to compete and survive in an ever-changing global business environment (Chen, Tang, Jin, Xie, \& Li, 2014), thus becoming an increasing area of interest to human resource management (HRM) researchers and practitioners (Cooke \& Saini, 2010). Innovative behavior is defined as the generation and implementation of ideas (Amabile, 2000), and is generally discretionary based on the nature of the employee's relationship with the organization or members within it (Ng \& Feldman, 2010). HRM practitioners place an enduring importance on facets of the organization that encourage employees to engage in innovative behavior, such as the provision of feedback from supervisors (Prieto \& Perez-Santana, 2014). Feedback provides detailed information to employees about how they are performing their job role (Dodd \& Ganster, 1996), and can therefore be adopted as a HRM practice to support employees perform effectively at work (Pulakos, Hanson, Arad, \& Moye, 2015). While there is evidence to suggest that team-based feedback is encouraged in many workplaces, the majority of academic studies have focused on the effects of feedback from managers, with few studies examining whether feedback from co-workers influences the innovative behavior of employees (Donia, O'Neill, \& Brutus, 2015; Smither, London, \& Reilly, 2005). Annual performance feedback evaluations from supervisors remain the 'norm' for the majority of organizations, although organizations that draw on and utilize feedback from wider employee groups may perform at a higher level (Murch, 2018).

Therefore, in the present study, we examine how the provision of feedback by others at work enhances innovative behavior. Building on prior work on innovation and HRM, we draw on the job demands-resources (JD-R) theory (Bakker \& Demerouti, 2017) and social exchange theory (Blau, 1964) to highlight two key pathways through which the provision of feedback can lead employees to engage in innovative behavior. First, we argue that feedback at work functions as an important job resource that is likely to foster more innovative behavior by heightening employees' work engagement (Alfes, Truss, Soane, Rees, \& Gatenby, 2013). Second, we contend that when feedback is not provided at work, employees perceive that the organization has not upheld its side of the psychological contract; thus, employees are less likely to engage in innovative behavior $(\mathrm{Ng}$, Feldman, \& Lam, 2010; Restubog, Bordia, \& Tang, 2007).

In examining the influence of feedback from others at work on innovative behavior, the present study investigates the relative importance of two distinct sources of feedback: that from 
the supervisor and that from other co-workers (Gabriel, Frantz, Levy, \& Hilliard, 2014). Supervisor feedback helps employees regulate their behavior in line with organizational expectations (Battistelli, Montani, \& Odoardi, 2013; Sommer \& Kulkarni, 2012), and includes giving compliments or providing advice on how best to perform a task (Gabriel et al., 2014; Vigoda-Gadot \& Angert, 2007). Compared to supervisor feedback, co-worker feedback tends to occur more frequently when colleagues provide informal advice to each other at work over how best to perform their job role (Zhou, 2003).

In the HRM literature, there is an underlying assumption that feedback from the supervisor is the key source of feedback for employees, even under the 360-degree or multi-source feedback models (e.g., Atwater, Waldman, \& Brett, 2002; Battistelli et al., 2013; Gabriel et al., 2014; Kuvaas, Buch, \& Dysvik, 2017; Vigoda-Gadot \& Angert, 2007). This assumption is predicated on classic feedback literature (see Latham \& Yukl, 1975) that argues that when employees receive feedback from those who exert control over them at work, employees' in-role performance is likely to increase. To date, current knowledge regarding which source of feedback is more influential in enhancing the innovative behavior of employees and, specifically, whether co-worker feedback may act as a supplementary resource for employees when supervisor feedback is lacking. Therefore, in addition to examining the mediating mechanisms linking supervisor feedback to employees' innovative behavior, the present study examines whether co-worker feedback moderates the influence of supervisor feedback on the mediated relationships. Figure 1 depicts our research model.

The present study makes three key contributions to the literature. First, it makes an important contribution by examining the distinct mechanisms that mediate the influence of supervisor feedback on employees' innovative behavior as predicted by the JD-R model and social exchange theory. In particular, this study helps us to explain the exact process by which the provision of feedback by the supervisor transmits its effects on employee innovative behavior. In doing so, we examine whether supervisor feedback not only functions as a valuable job resource that enables employees to engage in innovative behavior by fostering their work engagement, but also enhances their innovative behavior by reducing their perceptions of psychological contract breach and strengthening the social exchange relationship between the employee and the organization. Second, the study makes a further contribution by examining a key boundary condition of the supervisor feedback-innovative behavior relationship, namely, the provision of 
feedback by co-workers. More specifically, our study investigates whether co-worker feedback attenuates the positive influence of supervisor feedback on employees' innovative behavior. Although researchers have started to examine the influence of feedback provision on employees' behavior at work (Belschak \& Den Hartog, 2009; Whitaker, Dahling, \& Levy, 2007), they have yet to examine the relative influence of co-worker and supervisor feedback and how these sources of feedback might interact to predict work engagement and psychological contract breach and subsequently fosters innovative behavior among employees. Third, by examining the importance of co-workers as a source of feedback, this study develops our understanding of psychological contracts, in terms of highlighting whether employees look beyond their supervisors as the sole agents of the organization, to consider co-workers as representatives of their organization who can also deliver on the psychological contract promise of effective feedback on behalf of the organization.

Furthermore, our study contributes to practice by highlighting the importance to organizations of encouraging supervisors and co-workers to provide constructive feedback to employees (Alvero, Bucklin, \& Austin, 2001; Whitaker et al., 2007). We suggest that HR managers not only offer training to supervisors and co-workers on how to provide effective feedback to employees (Morrison \& Robinson, 1997; Robinson, Kraatz, \& Rousseau, 1994), but also train employees on how to use the feedback given to them to their own advantage (Ashford \& Cummings, 1985). Because our study is undertaken in the Chinese Civil Service, we also offer recommendations for HR managers seeking to increase innovative behavior within the Chinese public sector.

Insert Figure 1 about here

\section{THEORETICAL BACKGROUND AND HYPOTHESES}

Innovative behavior has quickly become a growing area of interest in the HRM literature (Cooke \& Saini, 2010), with several studies demonstrating a positive link between empowering HRM practices and innovative employee behavior (e.g., Do, Budhwar, \& Patel, 2018; Zhou, Hong, \& Liu, 2013). Innovation comprises idea generation, occurring when employees generate new ideas through exploration, experimentation, and risk taking (Miron-Spektor, Erez, \& Naveh, 2011), and idea implementation, in which employees and the organization put ideas into practice, which 
generally requires support (resources, funding, and time), integration with existing systems, and revision of the ideas (Alexander \& Van Knippenberg, 2014; West, 2002). Ng and Feldman (2010) presented three means by which employees can contribute to innovation within their organization: first, through the generation of new ideas; second, through communicating new ideas to their coworkers and supervisors; and third, through working to implement the ideas they or their coworkers have developed into innovations. Each of these is a discretionary behavior on the part of the employee that is often strongly affected by the nature of the relationship between the employee and the supervisor ( $\mathrm{Ng} \&$ Feldman, 2010). This point is consistent with findings outside the HRM literature that show that high quality exchange relationships between supervisors and employees lead to higher levels of employee innovative behavior (e.g., Wang, Fang, Qureshi \& Janssen, 2015).

\section{Feedback and Innovative Behavior}

The HRM literature is littered with differing conceptualizations of feedback (e.g., Gabriel, Frantz, Levy, \& Hilliard, 2014; Kuvaas, Buch, \& Dysvik, 2017; Luffarelli, Gonçalves, \& Stamatogiannakis, 2016). In general, feedback in a work context refers to the provision of advice by others at work, usually the supervisor, on an employee's behavior and job performance. Feedback provision can be through giving complements, increasing responsibilities, and providing challenging assignments. From this feedback, employees can gain useful knowledge about performance-related problems, career progression, completing tasks, and whether they are displaying positive or negative behavior at work (Battistelli et al., 2013; Sommer \& Kulkarni, 2012).

In acknowledging that employees rely on an ecosystem of external feedback from various sources (e.g., supervisors, co-workers, and clients) to enhance innovative behavior (Sijbom, Anseel, Crommelinck, De Beuckelaer, \& De Stobbeleir, 2017), this study considers two major sources of feedback at the workplace, that of the supervisor and co-worker. To distinguish between supervisor and co-worker feedback for our study, we draw upon Zhou's conceptualization of supervisor feedback (Zhou, 2003) and co-worker feedback (Zhou \& George, 2001). Zhou (2003, p. 415) defines supervisor feedback as the "extent to which supervisors provide their employees with helpful or valuable information that enables the employees to learn, develop, and make improvements on the job". She argues that the provision of feedback by supervisors increases the 
intrinsic motivation of employees (i.e., work engagement) to go above and beyond the basic requirements stipulated in their contract (i.e., engage in innovative behavior). When feedback is not provided, employees are demotivated (i.e., because a lack of feedback fosters their perceptions of psychological contract breach) and less likely to engage in innovative behavior. Co-worker feedback is "helpful or valuable information...that enables an employee to make improvements on the job" (Zhou \& George, 2001, p. 685), and, as Zhou and George suggest, is conducive to employees' generation of new and useful ideas. While the relationship between feedback and extra role behavior has been the subject of empirical investigation (Vigoda-Gadot \& Angert, 2007), we nonetheless have limited understanding of the mechanisms that underpin the relationship between feedback provision and innovative behavior. Drawing on Zhou's propositions, we argue that feedback influences employees' innovative behavior through increasing their work engagement and reducing their feelings of psychological contract breach.

\section{Mediating Influence of Work Engagement}

Work engagement is a positive, work-related state that is characterized by the individual having high levels of vigor, absorption, and dedication at work (Schaufeli \& Bakker, 2004). An individual shows vigor when they have high levels of resilience in difficult situations; shows absorption by being immersed in their work such that time passes quickly; and shows dedication by being deeply involved in their work (Boon \& Kalshoven, 2014; Schaufeli \& Bakker, 2004; Shantz, Alfes, \& Latham, 2016). Work engagement has previously been linked to job satisfaction (Hakanen \& Schaufeli, 2012) and task performance (Bakker, Demerouti \& Verbeke, 2004) and has been found to be negatively related to turnover intention (Shantz et al., 2016). Prior work shows that through the adoption of HR practices such as the provision of feedback, organizations can foster high performance in employees by eliciting high levels of work engagement (Boxall \& Macky, 2009).

To understand how organizations can foster employees' work engagement, scholars have drawn on the JD-R model (Bakker et al., 2004). The JD-R model argues that for employees to be engaged at work, they must have resources such as rewards, training, and feedback (Boon \& Kalshoven, 2014). Once these resources are provided by the organization, work engagement is more likely to occur (van Wingerden, Derks, \& Bakker, 2017). Feedback, as a key resource, allows employees to effectively complete their job tasks, because they are given accurate performance information to act upon and amend if necessary (Bakker \& Demerouti, 2017), and has been shown 
to predict positive work behavior (Sommer \& Kulkarni, 2012). Compared to other HRM resources such as developmental assignments, extra training, or financial incentives, feedback can be provided by an employee's direct supervisor at low cost to the organization. By taking the time to deliver feedback, the supervisor signals to an employee that he or she is making a personalized commitment to the development and growth of the employee (Alfes et al., 2013).

In addition to fostering the work engagement of employees, provision of feedback by the supervisor is also likely to foster positive work attitudes and behavior among employees (Bakker \& Schaufeli, 2008; Xanthopoulou, Bakker, Demerouti, \& Schaufeli, 2009). We therefore expect that when employees receive feedback from their supervisor, they obtain important resources in the form of work-specific advice that enables them to deal with their job demands. This fosters work engagement and begets the motivational process whereby employees are more likely to go beyond their job requirements to engage in innovative behavior at work (Bakker \& Schaufeli, 2008). Specifically, engaged employees demonstrate absorption, vigor, and dedication in the workplace (Schaufeli \& Bakker, 2004). As engaged employees are absorbed in the work they do, they are cognitively vigilant, seeking opportunities to improve their work. Demonstrating vigor, engaged employees have the mental resilience to generate new ideas, even when past ideas have failed, and as employees are dedicated to their work, they display a commitment to implement the ideas at work i.e., exhibit innovative behavior (Agarwal, Datta, Blake-Beard, \& Bhargava, 2012). Furthermore, because engaged employees tend to feel more spirited, they may complete their dayto-day tasks more quickly, which allows them additional time and resources to invest in innovative approaches to completing their work (Alfes et al., 2013). Thus, we expect that employees who are engaged in their work are more likely to engage in innovative behavior. This leads us to the following:

Hypothesis 1: Work engagement positively mediates the relationship between supervisor feedback and innovative behavior.

\section{Mediating Influence of Psychological Contract Breach}

While the previous section discussed the motivational effects of supervisor feedback on innovative behavior through enhancing work engagement, this section examines the demotivation effects when feedback is not forthcoming. Therefore, we draw on the mediating mechanism of psychological contract breach. The psychological contract refers to a set of beliefs that an 
individual holds regarding the terms and conditions of the reciprocal exchange relationship between themselves and another person or entity (Rousseau, 1995). In a workplace setting, employees hold expectations about what their employers owe them in return for the effort they exert, "which creates an enduring mental model of the employment relationship" (Chen, Tsui, \& Zhong, 2008, p. 528). To explain the willingness of employees to exert extra effort or a lack thereof in the case of psychological contract breach, scholars have commonly drawn upon social exchange theory (e.g. Chen et al., 2008; Ng et al., 2010; Restubog et al., 2007), which highlights the importance of reciprocated social exchange between two parties in a relationship (Blau, 1964). When employees believe that the other party has upheld its side of the psychological contract, social exchange theory presumes they will reciprocate in the form of desired behavior. In contrast, when the other party has not upheld its side of the contract, this behavior is less likely to be forthcoming due to a breach in the psychological contract (Morris, Hassard, \& McCann, 2006). Therefore, the psychological contract has been regarded as an important framework for understanding macro and micro changes to the employment relationship that affect employees' discretionary behavior at work, such as innovative behavior (Parker, Williams, \& Turner, 2006).

Research has highlighted various adverse employee attitudes and behaviors that result from the breach of a psychological contract, including lower levels of trust, satisfaction, and commitment (see Bal, De Lange, Jansen, \& Van Der Velde, 2008 for a meta-analysis), higher levels of turnover intention and actual turnover, and increased in-role performance (see Zhao, Wayne, Glibkowski, \& Bravo, 2007 for a meta-analysis). Employees may also downgrade their contributions in terms of discretionary organizational behavior that go beyond the boundaries of the formal employment contract and require extra effort such as organizational citizenship behavior (Zhao et al., 2007) and innovation-related behavior (Griffin, Neal, \& Parker, 2007; Parker et al., 2006). Such responses serve as means of restoring balance to the social exchange relationship.

Thus far, the literature has typically assumed that immediate supervisors are the sole key agents that cognitively represent the organization in the psychological contract between employees and organizations (Lester, Turnley, Bloodgood, \& Bolino, 2002; Tekleab \& Taylor, 2003), and therefore charged with the responsibility of creating and maintaining the psychological contract (e.g., fulfilling promises of providing timely and effective feedback) on behalf of the anthropomorphized organization (Cropanzano, Byrne, Bobocel, \& Rupp, 2001; Lavelle, Rupp, \& 
Brockner, 2007). This outcome is largely due to the high level of physical and psychological proximity to subordinates and the close bonds that are developed through activities such as the supervision of work tasks (Lee \& Taylor, 2014). In supervisor-employee relationships, there is an expectation on the part of employees that their supervisor will provide them with feedback on their work (Steelman, Levy, \& Snell, 2004). In fact, the provision of fair and timely performance feedback has been considered an integral HR practice that is not only essential to the maintenance of the psychological contract (Robinson et al., 1994) but also contributes to molding the employees' perceptions of how the organization will treat its employees (Guzzo \& Noonan, 1994). These perceptions, in turn, play an important role in shaping employees' cognitive evaluations of psychological contract breach and/or attainment (Tran Huy \& Takahashi, 2017) and affect their subsequent attitudinal and behavioral responses (Rousseau \& Greller, 1994).

Following this logic, if a supervisor does not provide the employee with feedback, the employee will not feel valued by the supervisor. Given that an employee typically sees the supervisor as the main representative of the organization, this behavior signals to employees that the organization has not provided them with sufficient support and will likely result in heightened employee perceptions of psychological contract breach on the part of the organization (Restubog et al., 2007). Previous research has indicated that perceptions of psychological contract breach are likely to invoke negative reciprocation responses, such as lower levels of proactive behavior (Robinson et al., 1994) and an increase in work neglect (Lemire \& Rouillard, 2005). As such, we expect that psychological contract breach, in turn, is likely to lead employees to focus only on meeting the responsibilities detailed in their work contract and reduce discretionary innovative behavior that benefits the supervisor and organization more generally (Turnley, Bolino, Lester, \& Bloodgood, 2003). Thus:

Hypothesis 2: Psychological contract breach negatively mediates the relationship between supervisor feedback and innovative behavior.

\section{The Moderating Role of Co-Worker Feedback}

In the previous sections, we argued that employees engage in innovative behavior when they are provided with high levels of feedback from their supervisor due to higher levels of work engagement and employee perceptions of lower psychological contract breach. However, it is important to note that the employee-supervisor relationship does not occur in a virtual vacuum, 
and that there are other factors that influence this relationship (Rousseau, 2004; Shalley \& Gilson, 2004). Further to this point, researchers have also noted that employees rely on feedback from other sources than supervisors (e.g., co-workers) in improving innovation-related behaviors such as creative performance (Sijbom et al., 2017) and generation of creative ideas (Dokko, Kane, \& Tortoriello, 2013).

Drawing on the JD-R model, we argue that co-worker feedback will attenuate the positive influence of supervisor feedback on employees' willingness to engage in innovative behavior by fostering their work engagement. More specifically, we argue that when employees obtain minimal levels of feedback from co-workers (e.g., feedback on the quality of their work, how to complete a complex task, or how to deal with a difficult client), they are not furnished with the resources needed to do the job. In such a situation, supervisor feedback is more strongly related to work engagement, because employees do not receive feedback from anyone else in the workplace (London \& Smither, 2002; Steelman et al., 2004). In contrast, when employees obtain feedback from their co-workers, they are not as dependent upon feedback from their supervisor because they are receiving the resources they need to deal with their job demands from a supplementary source (Bakker \& Demerouti, 2007). In this case, feedback from supervisors may be less strongly related to work engagement and therefore have a weaker influence on innovative behavior. This leads us to:

Hypothesis 3: Co-worker feedback will moderate the mediated relationship between supervisor feedback and innovative behavior through work engagement such that the mediated relationship will be weaker under high levels of co-worker feedback than under low levels of co-worker feedback.

Similarly, we argue that co-worker feedback will also moderate the influence of supervisor feedback on innovative behavior through employees' perceptions of psychological contract breach. Despite the longstanding assumption that direct supervisors are the main agents representing the organization (Lester et al., 2002; Robinson \& Morrison, 2000; Tekleab \& Taylor, 2003), recent research has since challenged this assumption, calling for research to adopt a multifocal perspective in examining psychological contracts (Alcover, Ramon, Turnley, \& Bolino, 2017). That is, to consider the effect of co-workers and peers as potential agents of the organization whose actions (or inactions) and messages communicated to the employee may accumulate and 
shape their evaluations of psychological contract breach and fulfilment (Marks, 2001). This point is particularly salient in today's context, in which work is increasingly organized in teams and in which the most proximal relationships are becoming those between co-workers within the work group, in contrast to the single, dyadic supervisor-employee relationship, which has been the subject of significant empirical investigation (Muethel, Gehrlein, \& Hoegl, 2012). Emphasizing the notion of co-workers as vital agents in the social exchange relationship, Rousseau (2004) argues that co-workers are an important source of information for individuals to determine what behavior they owe the organization.

Drawing on social exchange theory, we argue that when feedback from co-workers and supervisors is not forthcoming, employees will perceive that the organization has not upheld its part of the psychological contract (Restubog et al., 2007), and will therefore be less likely to reciprocate with innovative behavior. If feedback from supervisors is not forthcoming but the employee is receiving feedback from their co-workers, this feedback from co-workers will act as a supplement to the lack of supervisor feedback and enhance employees' perceptions that the organization has upheld its side of the psychological contract, leading employees to reciprocate in the form of positive behavior (Chiaburu \& Harrison, 2008). Therefore, when employees receive feedback from their co-workers, they are less dependent upon supervisor feedback to determine whether the organization has upheld its side of the psychological contract. This leads us to:

Hypothesis 4: Co-worker feedback will moderate the mediated relationship between supervisor feedback and innovative behavior through psychological contract breach such that the mediated relationship will be weaker under high levels of co-worker feedback than under low levels of coworker feedback.

\section{METHOD}

\section{Participants and Procedures}

In the present study, the sample comprised civil servants located in a prefecture-level city in Shandong Province, China. Innovative behavior is particularly needed in the Chinese public sector to ensure that outdated processes and procedures do not stifle the unprecedented economic progress that provides legitimacy for the government as an institution that creates public value (Miao, Newman, Schwarz, \& Cooper, 2010). The shift from a bureaucracy that focuses on the enforcement of rules and regulations to a provider of high-quality services (Jing \& Osborne, 2017) 
creates an 'innovation imperative' at all levels (Jordan, 2014), particularly among front-line employees who are responsible for most innovations in government (Borins, 2000). To facilitate innovative behavior, the Chinese government has created incentives, such as the Innovations and Excellence in Chinese Local Governance awards program that bestows enormous prestige and monetary rewards of up to 50,000 RMB on its winners (Wu, Ma, \& Yang, 2013). Two government bureaus (a water resource bureau and an environmental bureau) were approached and asked whether they were willing to participate in the study. For employees to participate, they were required to have close contact with their direct supervisor, and they had to work in teams such that they interacted with co-workers on a daily basis. The survey questions were administered to two sources (employees and their direct supervisors) at three different points in time, reducing common method bias associated with self-report data (Podsakoff, MacKenzie \& Podsakoff, 2012).

A member of the research team visited each of the bureaus on three separate occasions to collect the data. At each time point, the researcher explained to the participants the purpose of the research, that participation was voluntary, and that answers could be withdrawn at any time. Informed consent was obtained from all participants, and there was no pressure to participate. The researcher then left the participant alone in a meeting room to complete the survey. To ensure confidentiality, the surveys were coded with a unique identification number to match the employees with their supervisor.

At time one, employees were asked to provide their demographic details and to rate the level of feedback that they received from their supervisor and their co-workers. One month later, at time two, the employees who responded to the first survey were asked to report on their level of work engagement and their perceptions of psychological contract breach. After another month, at time three, supervisors of the employees who had responded to the first two surveys were asked to rate the innovative behavior of each employee. Prior to the distribution of each survey, the questions were translated from English to Mandarin by bilingual research assistants using the backtranslation procedure (Brislin, 1993).

A total of 300 employees and 64 supervisors responded to the survey, resulting in a response rate of $78 \%$. The supervisors managed between three and nine employees that responded to the survey $(M=4.94 ; S D=1.18)$. The average age of the employees was $34(M=34.02 ; S D=$ 5.75), with $53 \%$ of the sample being female and $79 \%$ holding a college equivalent degree or higher. Employees had worked under their current supervisor for an average of four years $(M=3.84 ; S D$ 
$=2.47)$ and had worked for their current organization for an average of six years $(M=5.91 ; S D=$ 3.39).

\section{Measures}

For the purposes of this study, we utilized multi-item measures that have been used in previous studies. All variables were measured using a 5-point Likert scale where $1=$ strongly disagree and $5=$ strongly agree. Table 1 presents the means, standard deviations, and correlations of the study variables. As each of the variables is subjective (e.g., what one individual sees as feedback from a supervisor may be different from another's perception), the model is conceptualized and analyzed at the individual level.

Supervisor Feedback

Employee perceptions of the frequency and usefulness of feedback received by employees from their supervisors was measured using the supervisor's developmental feedback scale used by Zhou (2003). This measure contains three items: "My immediate supervisor often gives me developmental feedback", "While giving me feedback, my supervisor focuses on helping me to learn and improve", and "My supervisor provides me with useful information on how to improve my job performance”. In Zhou's (2003) study, she empirically distinguished supervisor feedback from supervisor close monitoring, which focuses on supervisors keeping tabs on employees rather than providing them with feedback to improve their job performance and career prospects.

\section{Co-worker Feedback}

Employee perceptions of the frequency and usefulness of feedback received by employees from their co-workers was measured using the Zhou and George (2001) useful feedback from coworkers' scale. The measure contains three items: "I find the feedback I receive from my coworkers very useful", "My co-workers provide me with valuable information about how to improve my job performance", and "The feedback I receive from my co-workers helps me improve my job performance". In their original study, Zhou and George (2001) used this scale to demonstrate how feedback from co-workers led to an increase in employee creativity.

\section{Work Engagement}

Employees' work engagement was measured using Schaufeli, Bakker and Salanova’s (2006) 9item measure of work engagement. A sample item is "I get carried away when I'm working". Psychological Contract Breach 
The 5-item measure by Robinson and Morrison (1995) was used to measure the level of psychological contract breach that employees felt towards their organization. A sample item is "My employer has broken many of its promises to me even though I've upheld my side of the deal".

\section{Innovative Behavior}

To measure innovative behavior, we asked supervisors to rate each employee's innovative behavior using Bysted and Hansen's (2015) 6-item innovative behavior scale. This measure of innovative behavior was validated in a public-sector sample such as the one used in this study and incorporates both idea generation (e.g., "He/she is creating new ideas for improvements") and idea implementation (e.g., "He/she is transforming innovative ideas into useful applications").

\section{Control Variables}

Age, gender, education, time working under the supervisor and time working for the organization were included as control variables because each variable has been shown to affect employees' innovative behavior (De Dreu, 2006).

\section{Common Method Bias Checks and Measurement Model}

We utilized several procedural remedies to address concerns over common method bias such as collecting the data across multiple time points from multiple sources, ensuring minimal ambiguity in the survey questions, and ensuring confidentiality through the use of individually sealed envelopes (Podsakoff et al., 2012). Siemsen, Roth, and Oliveira (2010) demonstrated that significant interaction effects (such as the ones displayed in this study) cannot be obtained if common method bias is present. If anything, the presence of common method bias would reduce the significance and magnitude of the interaction. We performed a confirmatory factor analysis to establish the discriminant validity of the study measures using a weighted least squares means and variance adjusted (WLSMV) estimator in Mplus, specifically designed for ordinal data such as those used in this study (Li, 2016). The hypothesized five-factor model in which each of the items load onto their corresponding factors (i.e., supervisor feedback, co-worker feedback, work engagement, psychological contract breach, and innovative behavior) yielded a good fit to the data $\chi^{2}(d f=289)=572, \mathrm{CFI}=.97, \mathrm{TLI}=.97, \mathrm{RMSEA}=.052(90 \% \mathrm{CI}[.045-.059])$. We compared the fit of the five-factor model with that of alternative models in which the items were loaded onto four, three, two, and a single factor (a variation of the Harman's single factor test). On each 
occasion, the five-factor model fit the data better than the alternative models (see Table 2). These results provide evidence for the discriminant validity of the measures used in this study.

Insert Table 1 about here

Insert Table 2 about here

\section{Analytical Strategy}

As the data were clustered within teams, there was non-independence of the data within our sample. To address the non-independence of the data, we used the TYPE=COMPLEX function within Mplus to correct for the clustering effects (Muthén \& Muthén, 2012). To test the hypotheses, two regression analyses in Mplus were conducted using the maximum likelihood estimator with robust standard errors. We used the Monte Carlo method of confidence interval construction for calculating the indirect effects in the moderated mediation models using the recommended 20,000 replications. To reduce issues associated with multicollinearity and to create the interaction term between supervisor feedback and co-worker feedback, all variables were zstandardized prior to their inclusion in the analysis (Tabachnick \& Fidell, 2013). The evaluations of the regression assumptions of normality and linearity, as well as the absence of multicollinearity, were satisfactory.

The first model ran the mediation hypotheses simultaneously (Table 3); the second ran the moderated mediation hypotheses simultaneously (Table 4). For ease of interpretation of the moderated mediation model, we modeled the moderation using Aiken and West's (1991) simple slopes technique, where the moderated effect was shown at one standard deviation above the mean, the mean, and one standard deviation below the mean. The results of the bootstrapping analyses with the conditional indirect effects can be found in Table 5.

\section{RESULTS}

Hypothesis 1 predicted that work engagement would positively mediate the relationship between supervisor feedback and innovative behavior, and hypothesis 2 proposed that psychological 
contract breach would negatively mediate the relationship between supervisor feedback and innovative behavior. As shown in Table 3, the indirect relationship between supervisor feedback and innovative behavior through work engagement was .04 (95\% confidence interval (CI) $.01, .10$ ) and through psychological contract breach was .06 (95\% CI .02, .11). Because zero was not contained in the $95 \%$ confidence intervals, hypotheses 1 and 2 were supported. With the presence of work engagement and psychological contract breach in the model, no significant relationship was found between supervisor feedback and innovative behavior.

Insert Table 3 about here

To test hypotheses 3 and 4, we first examined whether co-worker feedback moderated the relationship between supervisor feedback and both work engagement and psychological contract breach. The analysis indicated that there was a significant interaction in both cases (see Table 4). To demonstrate the nature of the interactions, we plotted the simple slopes analysis for each interaction as outlined by Aiken and West (1991). Figure 2 illustrates the interaction effect of supervisors and co-worker feedback on work engagement $(b=-.19, p<.05)$, and Figure 3 illustrates the interaction effect of supervisor and co-worker feedback on psychological contract breach $(b=.14, p<.01)$. We then calculated the indirect effect of supervisor feedback on innovative behavior through the mediating mechanisms of work engagement and psychological contract breach at different levels of the moderator (co-worker feedback). As seen in Table 5, when there were low levels of co-worker feedback, supervisor feedback had a significant indirect effect on innovative behavior through work engagement $(b=.06,95 \% \mathrm{CI}=.01, .15)$ and psychological contract breach $(b=.06,95 \% \mathrm{CI}=.03, .11)$. In contrast, when there were high levels of co-worker feedback, supervisor feedback did not have an indirect effect on innovative behavior through work engagement $(b=-.01,95 \% \mathrm{CI}=-.04, .02)$ and psychological contract breach $(b=.0195 \% \mathrm{CI}=-$ $.02, .03)$. These results provide support for hypotheses 3 and 4 . 


\section{DISCUSSION}

In the present study, we examined the influence of supervisor feedback on employees' innovative behavior and the mediating mechanisms that explain this influence. We found that employees' work engagement and perceptions of psychological contract breach fully mediated the influence of supervisor feedback on innovative behavior. First, in line with the tenets of the JD-R model, these findings suggest that employees who receive greater job resources in the form of feedback from their supervisor exhibit higher levels of work engagement. This fosters higher levels of vigor, absorption, and dedication to the job role, and in turn encourages employees to exhibit higher levels of innovative behavior (Bakker \& Schaufeli, 2008; Saks, 2006). These findings are also supportive of the general arguments espoused by social exchange theory, that is, that employees consider supervisor feedback part of what was promised to them under their psychological contract with the organization (Steelman et al., 2004). Specifically, more frequent and useful feedback from supervisors reduces employees' levels of psychological contract breach (Tran Huy \& Takahashi, 2017) as this exchange relationship is solidified by the feedback received (Cropanzano \& Mitchell, 2005). With reduced perceptions of psychological contract breach, employees are likely to feel more obligation to reciprocate the positive treatment from their supervisors in the form of innovative behavior.

By combining both social exchange theory and the JD-R model, this study highlights the causal link between supervisor feedback, work engagement, psychological contract breach, and innovative behavior. This study has shown that supervisor feedback decreases the possibility of psychological contract breach due to perceived reciprocity of resources (Xanthopoulou et al., 2009). In addition, these resources, such as feedback, can lead to innovative behavior through the 
development of work engagement (Alfes et al., 2013). These findings highlight the importance of supervisor feedback because it not only functions as a key job resource in fostering engagement and, in effect, innovative behavior, but is also considered an important facet promised to employees under their psychological contract with the organization. Additionally, these findings emphasize the pertinence of supervisor feedback to innovation, and they vindicate the decision of many large firms (e.g., Accenture, Adobe, Deloitte, and Microsoft) to remove their annual review process and instead focus on encouraging supervisors to provide regular feedback (Kuvaas et al., 2017).

Beyond examining the theoretical mechanisms of social exchange and JD-R underlying the relationship between supervisor feedback and innovative behavior, the present study investigated the moderating influence of co-worker feedback on the mediated relationships. While we demonstrated above the importance of positive supervisor feedback on innovative behavior, our findings suggest that co-worker feedback can buffer supervisor feedback to such an extent that any negative effects of poor supervisor feedback (e.g., feelings of psychological contract breach or work disengagement) are lessened due to the presence of co-worker feedback. As demonstrated, any perceived lack of supervisor feedback as a resource can have a negative effect on the exchange relationship between the employee and employer (Aggarwal \& Bhargava, 2009; Saks, 2006), possibly inhibiting innovative behavior (Ng \& Feldman, 2010). However, our findings suggest that co-worker feedback can act as a safety net. In scenarios in which supervisor feedback is not forthcoming, employees draw on co-worker feedback as a supplementary resource to deal with their job demands, keeping the employee engaged (Bakker \& Demerouti, 2017), maintaining the psychological contract (Rousseau, 2004), and subsequently fostering innovative behavior. This does not mean co-worker feedback can replace the importance or impact of supervisor feedback, rather the results indicate that co-worker feedback acted as a supplementary resource when supervisor feedback was not readily available.

We should note that the findings do not indicate that when co-worker feedback is high (i.e., +1 SD above our mean), the quantity of supervisor feedback decreases, or that supervisor feedback has a negative effect on engagement or innovative behavior. What the results do indicate is that when there are low levels of supervisor feedback (i.e., -1 SD below our mean), co-worker feedback can supplement the lack of supervisor feedback to build employee engagement and reduce feelings of psychological contract breach. Examination of our interaction plots (Figures 2 and 3) reveals 
that the conditions of high supervisor feedback and high co-worker feedback showed high levels of work engagement and low levels of psychological contract breach. In this condition, due to the resources that employees gain when they receive feedback from their co-workers, the added benefit of supervisor feedback on employees' work engagement and psychological contract breach is less compared with conditions in which employees are not receiving feedback from their coworkers. Taken together, our findings suggest that to enhance innovative behavior, organizations should encourage feedback to be delivered by both supervisors and co-workers rather than relying on only one source of feedback.

\section{Theoretical Implications}

The findings of this study lead to several theoretical implications. First, the present study extends the literature on innovation and HRM by improving our understanding of the mediating mechanisms linking supervisor feedback to employees' innovative behavior. Leveraging both the JD-R model and social exchange theory, the present study's findings make an important theoretical contribution by revealing that supervisors who provide feedback foster innovative employee behavior by not only reducing their perceptions of psychological contract breach but also by enhancing their work engagement.

From a JD-R perspective, for employees to engage in innovative behavior, they need the job resources to deal with the demands that result from their jobs (Bakker \& Demerouti, 2007). Our study has demonstrated that the resources which employees receive from their supervisors (i.e., feedback) help guard against resource depletion and job demands, and foster work engagement (Bakker \& Demerouti, 2017). This outcome, in turn, is likely to encourage employees to engage in innovative behavior that are beyond the expectations of their job role (Turnley et al., 2003). Additionally, contributing to the psychological contract literature, the present study's findings build upon existing evidence (e.g., Steelman et al., 2004) that supervisor feedback is an important aspect of the psychological contract an employee has with the organization. This feedback received from supervisors reduces employees' perceptions of psychological contract breach and, in return, leads employees to engage in higher levels of innovative behavior. A lack of supervisor feedback creates a situation in which psychological contract breach might occur, decreasing the likelihood that employees will engage in innovative behavior. 
Second, the study makes an important contribution by examining effects of the provision of feedback by co-workers on the mediated relationships between supervisor feedback and innovative behavior through work engagement and psychological contract breach. In particular, our finding is that the influence of supervisor support on innovative behavior through both mediators was not significant when co-worker feedback was high, suggesting that co-worker feedback is supplementary to supervisor feedback. Our findings suggest that when there is a lack of supervisor feedback, co-worker feedback acts as a useful resource for employees to utilize (Atwater et al., 2002), fostering employees' innovative behavior through eliciting their work engagement (Gruman \& Saks, 2011) and reducing their perceptions of psychological contract breach.

Third, in examining co-workers as potential agents of the organization who may reduce employees' perceptions of psychological contract breach by fulfilling perceived promises of adequate feedback, we answer Marks' (2001) and Alcover et al.'s (2017) calls for psychological contract research to consider the multi-agent context whereby the multiple and concurrent relationships that individual employees have with their supervisors or co-workers can influence perceptions of psychological contract breach (Bligh \& Carsten, 2005). Overall, the findings of our study demonstrate that co-workers' actions in terms of providing feedback do influence the extent to which employees' perceive that promises in their psychological contracts have been upheld by the organization. Rather than subscribing to the dominant assumption that the direct supervisor acts as the primary agent of the organization (Alcover et al., 2017), and is tasked with the responsibility of maintaining and fulfilling the psychological contract (Cropanzano et al., 2001), our study shows that there is value in considering how the actions (or inactions) of other individuals with whom employees have contact, such as co-workers, can also affect employees' psychological contract perceptions (Alcover et al., 2017; Marks, 2001). Additionally, our findings suggest that social exchange relationships between the employee and different organizational agents such as the supervisor and co-workers do not operate in isolation from one another but may exert significant effects on each other (Cole, Schaninger, \& Harris, 2002; Rupp \& Cropanzano, 2002). Although our findings do not suggest that supervisor feedback is more or less influential in fostering employees' innovative behavior than co-worker feedback, they show that in the absence of co-worker feedback, supervisor feedback is extremely important and that co-worker feedback can support the provision of resources and protection of the psychological contract. 


\section{Practical Implications}

This study has shown that feedback is a critical HRM practice that influences employees' innovative behavior at work. In line with prior work, we highlight the importance of organizations' encouraging supervisors and co-workers to provide constructive feedback to others in the workplace (Alvero et al., 2001; Whitaker et al., 2007). The use of feedback as an HRM practice is likely to be most effective in organizations that lack adequate resources to offer their employees developmental assignments, extra training, or financial incentives (Sommer \& Kulkarni, 2012). Additionally, applicability across organization size, such as small businesses and the public sector can occur due to the adaptability and elementary nature of feedback (Gong, Wang, Huang, \& Cheung, 2017). This practice becomes more relevant to the study context within the emerging dynamic economy of China, in which there is an increasing demand for workplace innovation (Budhwar, Varma, \& Patel, 2016).

HR managers and line managers should be aware of the need to assist employees in obtaining ongoing feedback from different sources within the organization, because our research has shown that in the absence of one source of feedback, other sources are critical in enhancing employees' innovative behavior. Therefore, organizations should not only encourage supervisors to provide feedback as part of the annual formal performance appraisal process (Brown, Kulik, \& Lim, 2016; Zheng, Diaz, Jing, \& Chiaburu, 2015) but also consider implementing appraisal feedback process for employees through which they can obtain more regular feedback from multiple sources, not only from their direct supervisor but also from other employees in the organization (Biron, Farndale, \& Paauwe, 2011; Kuvaas et al., 2017). As we have shown, feedback can promote employees' work engagement and perceptions that the organization is upholding its side of the psychological contract and subsequently foster employees' innovative behavior (Gruman \& Saks, 2011; Harris, 2001).

HR managers should not only offer training to supervisors and co-workers on how to provide effective feedback to employees (Brown et al., 2016) but also provide training to employees on how to use feedback to their advantage (Ashford \& Cummings, 1985; Presbitero \& Teng-Calleja, 2017). Feedback can also be integrated into additional HRM processes such as talent management (Al Ariss, Cascio, \& Paauwe, 2014; Gelens, Hofmans, Dries, \& Pepermans, 2014) 
and team development, whereby feedback is given simultaneously to team members to improve performance (Donia et al., 2015).

Our findings also offer implications for the Chinese Civil Service. One of the main purposes of the promulgation of the Provisional Regulations on State Civil Servants that established the modern Chinese Civil Service system in 1993 and the Civil Service Law that extended its scope in 2006 was to introduce a merit-based recruitment and promotion system. Promotions are an important motivator for many civil servants because they lead to a higher salary and more prestige and power (Wang, 2012). The findings of our study suggest that the provision of feedback could be introduced as a promotion criterion for civil servants in China. In China, innovation orientation became an officially recognized national strategy in 2006 (Jing \& Osborne, 2017). Despite the importance of public service innovations for the Chinese government's performance legitimacy (Jing, Cui, \& Li, 2015), civil servants have been described as "often reluctant to show self-initiated leadership unless it has been explicitly demanded or sanctioned by leaders" (Berman, 2010, p. 10). In a high power-distance culture such as China (Miao, Newman, Schwarz, \& Xu, 2013), supervisor support is crucial, and supervisors should encourage their subordinates to provide feedback to their colleagues to elicit innovative behavior.

\section{Limitations and Avenues for Future Research}

For this study, we asked participants to rate the frequency and usefulness of feedback they received from supervisors and co-workers more generally rather than the type (e.g., oral or written) or perceived constructiveness of the feedback (Kuvaas et al., 2017). Thus, we cannot provide more precise recommendations based on our study findings concerning what type of feedback from supervisors and co-workers is most effective in promoting innovative behavior among employees. Furthermore, we only examined feedback from supervisors and co-workers rather than other sources such as subordinates or customers. Future studies might therefore examine how the type, quality, and source of feedback influences the strength of the relationship between the provision of feedback and employees' innovative behavior. Because the present study was conducted in the Chinese Civil Service, we cannot conclusively determine that its findings are generalizable outside the specific institutional and cultural context in which it was conducted. However, we would argue that the overall pattern of our findings is universal due to many organizations in China now adopting Western management styles and ideas (King \& Zhang, 2014). Regardless, understanding 
how the model operates in other cultural contexts is important to ascertain whether co-worker feedback is as important in individualistic workforces as it appears to be in the collectivist workforce of China.

Finally, there is a push in the HRM literature to examine team or collaborative innovative behavior (Zhou, Hong, \& Liu, 2013). Therefore, we suggest that future research draw on collaboration-based theories, such as the PILAR model (Heslop, Stojanovski, Paul, \& Bailey, 2018), and feedback environment models (Gabriel et al., 2014) to understand how the feedback environment can create a psychologically safe workplace to increase innovative behavior. We suggest examining this relationship through innovative techniques such as social network analysis (Balkundi \& Kilduff, 2006), which allows researchers to measure tie strength, density, and centrality. This approach would also allow researchers to collect data on the levels of engagement of supervisors and co-workers, and obtain co-worker ratings of each other's innovative behavior.

\section{CONCLUSION}

Our study demonstrated that supervisors can enhance employees' innovative behavior through the provision of feedback. Consistent with the JD-R model and social exchange theory, we found that supervisor feedback increases work engagement and reduces psychological contract breach, which then influences innovative behavior. However, this relationship is contingent on the level of coworker feedback; when co-worker feedback was higher, the influence of supervisor feedback was not significant. These findings provide an important basis from which to develop future research and offer insights for HR managers into how they can utilize feedback within their organization to increase innovation. 


\section{REFERENCES}

Agarwal, U. A., Datta, S., Blake-Beard, S., \& Bhargava, S. (2012). Linking LMX, innovative work behaviour and turnover intentions: The mediating role of work engagement, Career Development International, 17, 208-230.

Aggarwal, U., \& Bhargava, S. (2009). Reviewing the relationship between human resource practices and psychological contract and their impact on employee attitude and behaviours: A conceptual model, Journal of European Industrial Training, 33, 4-31.

Aiken, L. S., \& West, S. G. (1991). Multiple regression: Testing and interpreting results. Newbury Park, CA.: Sage.

Al Ariss, A., Cascio, W. F., \& Paauwe, J. (2014). Talent management: Current theories and future research directions. Journal of World Business, 49, 173-179.

Alcover, C.-M., Ramón, R., Turnley, W. H, \& Bolino, M. C. (2017). Multi-dependence in the formation and development of the distributed psychological contract. European Journal of Work and Organizational Psychology, 26, 16-29.

Alexander, L., \& Van Knippenberg, D. (2014). Teams in pursuit of radical innovation: A goal orientation perspective, Academy of Management Review, 39, 423-438.

Alfes, K., Truss, C., Soane, E. C., Rees, C., \& Gatenby, M. (2013). The relationship between line manager behavior, perceived HRM practices, and individual performance: Examining the mediating role of engagement. Human Resource Management, 52, 839-859.

Alvero, A. M., Bucklin, B. R., \& Austin, J. (2001). An objective review of the effectiveness and essential characteristics of performance feedback in organizational settings (1985-1998). Journal of Organizational Behavior Management, 21, 3-29.

Amabile, T. M. (2000). Stimulate creativity by fueling passion. In E. Locke (Ed.), Handbook of principles of organizational behavior (pp. 331-341). Malden, MA: Blackwell.

Ashford, S. J., \& Cummings, L. L. (1985). Proactive feedback seeking: The instrumental use of the information environment. Journal of Occupational Psychology, 58, 67-79.

Atwater, L. E., Waldman, D. A., \& Brett, J. F. (2002). Understanding and optimizing multisource feedback. Human Resource Management, 41, 193-208.

Bakker, A. B., \& Demerouti, E. (2007). The job demands-resources model: State of the art. Journal of Managerial Psychology, 22, 309-328.

Bakker, A. B., \& Demerouti, E. (2017). Job demands-resources theory: Taking stock and looking forward. Journal of Occupational Health Psychology, 22, 273-285.

Bakker, A. B., Demerouti, E., \& Verbeke, W. (2004). Using the job demands-resources model to predict burnout and performance. Human Resource Management, 43, 83-104.

Bakker, A. B., \& Schaufeli, W. B. (2008). Positive organizational behavior: Engaged employees in flourishing organizations. Journal of Organizational Behavior, 29, 147-154.

Bal, P. M., De Lange, A. H., Jansen, P. G., \& Van Der Velde, M. E. (2008). Psychological contract breach and job attitudes: A meta-analysis of age as a moderator. Journal of Vocational Behavior, 72, 143-158.

Balkundi, P., \& Kilduff, M. (2006). The ties that lead: A social network approach to leadership. The Leadership Quarterly, 17, 419-439.

Battistelli, A., Montani, F., \& Odoardi, C. (2013). The impact of feedback from job and task autonomy in the relationship between dispositional resistance to change and innovative work behaviour. European Journal of Work and Organizational Psychology, 22, 26-41.

Belschak, F. D., \& Den Hartog, D. N. (2009). Consequences of positive and negative feedback: The impact on emotions and extra-role behaviors. Applied Psychology: An International Review, 58, 274-303.

Berman, E. M. (2010), Public administration in East Asia: Common roots, ways, and tasks. In E. M. Berman, M. J. Moon and H. Choi (Eds.), Public administration in East Asia: Mainland China, Japan, South Korea, and Taiwan (pp. 1-29). New York: Taylor and Francis.

Biron, M., Farndale, E., \& Paauwe, J. (2011). Performance management effectiveness: Lessons from world-leading firms. International Journal of Human Resource Management, 22, 1294-1311.

Blau, P. M. (1964). Exchange and power in social life. New York: Wiley.

Bligh, M. C., \& Carsten, M. K. (2005). Post-merger psychological contracts: exploring a "multiple foci" conceptualization. Employee Relations, 27, 495-510.

Boon, C., \& Kalshoven, K. (2014). How high-commitment HRM relates to engagement and commitment: The moderating role of task proficiency. Human Resource Management, 53, 403-420.

Borins, S. F. (2000). Loose cannons and rule breakers, or enterprising leaders? Some evidence about innovative public managers. Public Administration Review 60, 498-507. 
Boxall, P., \& Macky, K. (2009). Research and theory on high-performance work systems: Progressing the high-involvement stream. Human Resource Management Journal, 19, 323.

Brislin, R. (1993). Understanding culture's influence on behavior. Fort Worth, TX: Harcourt Brace Publishers.

Brown, M., Kulik, C. T., \& Lim, V. (2016). Managerial tactics for communicating negative performance feedback. Personnel Review, 45, 969-987.

Budhwar, P. S., Varma, A., \& Patel, C. (2016). Convergence-divergence of HRM in the AsiaPacific: Context-specific analysis and future research agenda. Human Resource Management Review, 26, 311-326.

Bysted, R., \& Hansen, J. R. (2015). Comparing public and private sector employees' innovative behaviour: Understanding the role of job and organizational characteristics, job types, and subsectors. Public Management Review, 17, 698-717.

Chen, Y., Tang, G., Jin, J., Xie, Q., \& Li, J. (2014). CEOs' transformational leadership and product innovation performance: The roles of corporate entrepreneurship and technology orientation. Journal of Product Innovation Management, 31, 2-17.

Chen, Z. X., Tsui, A. S., \& Zhong, L. (2008). Reactions to psychological contract breach: A dual perspective. Journal of Organizational Behavior, 29, 527-548.

Chiaburu, D., \& Harrison, D. (2008). Do peers make the place? Conceptual synthesis and metaanalysis of coworker effects on perceptions, attitudes, OCBs, and performance. Journal of Applied Psychology, 93, 1082-1103.

Cole, M., Schaninger, W., \& Harris, S. (2002). The workplace social exchange network: A multilevel, conceptual examination. Group \& Organization Management, 27, 142-167.

Cooke, F. L., \& Saini, D. S. (2010). (How) Does the HR strategy support an innovation oriented business strategy? An investigation of institutional context and organizational practices in Indian firms. Human Resource Management, 49, 377-400.

Cropanzano, R., Byrne, Z. S., Bobocel, D. R., \& Rupp, D. E. (2001). Moral virtues, fairness heuristics, social entities, and other denizens of organizational justice. Journal of Vocational Behavior, 58, 164-209.

Cropanzano, R, \& Mitchell, MS. (2005). Social exchange theory: An interdisciplinary review, Journal of Management, 31, 874-900.

De Dreu, C. K. W. (2006). When too little of too much hurts: Evidence for a curvilinear relationship between conflict and innovation in teams. Journal of Management, 32, 83108.

Do, H., Budhwar, P. S., \& Patel, C. (2018). Relationship between innovation-led hr policy, strategy, and firm performance: A serial mediation investigation, Human Resource Management, 57, 1271-1284.

Dodd, N. G., \& Ganster, D. C. (1996). The interactive effects of variety, autonomy, and feedback on attitudes and performance. Journal of Organizational Behavior, 17, 329-347.

Donia, M., O'Neill, T. A., \& Brutus, S. (2015). Peer feedback increases team member performance, confidence and work outcomes: A longitudinal study. Paper presented at the Academy of Management Proceedings.

Dokko, G., Kane, A. A., \& Tortoriello, M. (2014). One of us or one of my friends: How social identity and tie strength shape the creative generativity of boundary-spanning ties. Organization Studies, 35, 703-726.

Gabriel, A. S., Frantz, N. B., Levy, P. E., \& Hilliard, A. W. (2014). The supervisor feedback environment is empowering, but not all the time: Feedback orientation as a critical moderator. Journal of Occupational and Organizational Psychology, 87, 487-506.

Gelens, J., Hofmans, J., Dries, N., \& Pepermans, R. (2014). Talent management and organisational justice: Employee reactions to high potential identification. Human Resource Management Journal, 24, 159-175.

Gong, Y., Wang, M., Huang, J.-C., \& Cheung, S. Y. (2017). Toward a goal orientation-based feedback-seeking typology: Implications for employee performance outcomes. Journal of Management, 43, 1234-1260.

Griffin, M. A., Neal, A., \& Parker, S. K. (2007). A new model of work role performance: Positive behavior in uncertain and interdependent contexts. Academy of Management Journal, 50, 327-347.

Gruman, J. A., \& Saks, A. M. (2011). Performance management and employee engagement. Human Resource Management Review, 21, 123-136.

Guzzo, R. A., \& Noonan, K. A. (1994). Human resource practices as communications and the psychological contract. Human Resource Management, 33, 447-462. 
Hakanen, J. J., \& Schaufeli, W. B. (2012). Do burnout and work engagement predict depressive symptoms and life satisfaction? A three-wave seven-year prospective study. Journal of Affective Disorders, 141, 415-424.

Harris, L. (2001). Rewarding employee performance: Line managers' values, beliefs and perspectives. The International Journal of Human Resource Management, 12, 1182-1192.

Heslop, B., Stojanovski, E., Paul, J., \& Bailey, K. (2018). PILAR: A model of collaboration to encapsulate social psychology, Review of General Psychology, 22, 321-333.

King, P., \& Zhang, W. (2014). Chinese and Western leadership models: A literature review. Journal of Management Research, 6, 1-21.

Kuvaas, B., Buch, R., \& Dysvik, A. (2017). Constructive supervisor feedback is not sufficient: Immediacy and frequency is essential. Human Resource Management, 56, 519-531.

Jing, Y., Cui, Y., \& Li, D. (2015). The politics of performance measurement in China. Policy and Society, 34, 49-61.

Jing, Y., \& Osborne, S. P. (2017). Public service innovations in China: An introduction. In Y. Jing \& S. P. Osborne (Eds.), Public service innovations in China (pp. 1-24). Singapore: Palgrave-Macmillan.

Jordan, S. R. (2014). The innovation imperative: An analysis of the ethics of the imperative to innovate in public sector service delivery. Public Management Review 16, 67-89.

Latham, G. P., \& Yukl, G. A. (1975). A review of research on the application of goal setting in organizations. Academy of Management Journal, 18, 824-845.

Lavelle, J., Rupp, D. E., \& Brockner, J. (2007). Multifoci perspectives and target similarity in organizational behavior: Bridging justice, commitment, and organizational citizenship behavior. Journal of Management, 33, 378-394.

Lee, J., \& Taylor, M. S. (2014). Dual roles in psychological contracts: When managers take both agent and principal roles. Human Resource Management Review, 24, 95-107.

Lemire, L., \& Rouillard, C. (2005). An empirical exploration of psychological contract violation and individual behaviour: The case of Canadian federal civil servants in Quebec. Journal of Managerial Psychology, 20(2), 150-163.

Lester, S. W., Turnley, W. H., Bloodgood, J. M., \& Bolino, M. C. (2002). Not seeing eye to eye: Differences in supervisor and subordinate perceptions of and attributions for psychological contract breach. Journal of Organizational Behavior, 23, 39-56.

Li, C. H. (2016). Confirmatory factor analysis with ordinal data: Comparing robust maximum likelihood and diagonally weighted least squares. Behavior Research Methods, 48, 936949.

London, M., \& Smither, J. W. (2002). Feedback orientation, feedback culture, and the longitudinal performance management process. Human Resource Management Review, 12, 81-100.

Luffarelli, J., Gonçalves, D., \& Stamatogiannakis, A. (2016). When feedback interventions backfire: Why higher performance feedback may result in lower self-perceived competence and satisfaction with performance, Human Resource Management, 55, 591614.

Marks, A. (2001). Developing a multiple foci conceptualization of the psychological contract. Employee Relations, 23, 454-469.

Miao, Q., Newman, A., Schwarz, G., \& Cooper, B. (2018). How leadership and public service motivation enhance innovative behavior. Public Administration Review, 78, 71-81.

Miao, Q., Newman, A., Schwarz, G., \& Xu, L. (2013). Participative leadership and the organizational commitment of civil servants in China: The mediating effects of trust in supervisor. British Journal of Management, 24, S76-S92.

Miron-Spektor, E., Erez, M., \& Naveh, E. (2011). The effect of conformist and attentive-to-detail members on team innovation: Reconciling the innovation paradox, Academy of Management Journal, 54, 740-760.

Morris, J., Hassard, J., \& McCann, L. (2006). New organizational forms, human resource management and structural convergence? A study of Japanese organizations. Organization Studies, 27, 1485-1511.

Morrison, E. W., \& Robinson, S. L. (1997). When employees feel betrayed: A model of how psychological contract violation develops. Academy of Management Review, 22, 226-256.

Muethel, M., Gehrlein, S., \& Hoegl, M. (2012). Socio-demographic factors and shared leadership behaviors in dispersed teams: Implications for human resource management. Human Resource Management, 51, 525-548.

Murch, G. (2018). Feedback cultures stuck in the 1940's. Retrieved from https://www.hrdaily.com.au/nl06_news_selected.php?act=2\&nav=13\&selkey=5020

Muthén, L. K., \& Muthén, B. O. (2012). Mplus user's guide (7th ed.). Los Angeles, CA: Muthén \& Muthén. 
Ng, T. W., \& Feldman, D. C. (2010). The impact of job embeddedness on innovation-related behaviors. Human Resource Management, 49, 1067-1087.

Ng, T. W., Feldman, D. C., \& Lam, S. S. (2010). Psychological contract breaches, organizational commitment, and innovation-related behaviors: A latent growth modeling approach. Journal of Applied Psychology, 95, 744-751.

Parker, S. K., Williams, H. M., \& Turner, N. (2006). Modeling the antecedents of proactive behavior at work. Journal of Applied Psychology, 91, 636-652.

Podsakoff, P. M., MacKenzie, S. B., \& Podsakoff, N. P. (2012). Sources of method bias in social science research and recommendations on how to control it. Annual Review of Psychology, 63, 539-569.

Presbitero, A., \& Teng-Calleja, M. (2017). Subordinate's proactivity in performance planning: Implications for performance management systems. Asia Pacific Journal of Human Resources, in press, 1-16.

Prieto, I., \& Perez-Santana, P. (2014). Managing innovative work behavior: The role of human resource practices. Personnel Review, 43, 184-208.

Pulakos, E. D., Hanson, R. M., Arad, S., \& Moye, N. (2015). Performance management can be fixed: An on-the-job experiential learning approach for complex behavior change. Industrial and Organizational Psychology, 8, 51-76.

Restubog, S. L. D., Bordia, P., \& Tang, R. L. (2007). Behavioural outcomes of psychological contract breach in a non-western culture: The moderating role of equity sensitivity. British Journal of Management, 18, 376-386.

Robinson, S., Kraatz, M. S., \& Rousseau, D. M. (1994). Changing obligations and the psychological contract: A longitudinal study. Academy of Management Journal, 37, 137152.

Robinson, S., \& Morrison, E. W. (1995). Psychological contracts and OCB: The effect of unfulfilled obligations on civic virtue behavior. Journal of Organizational Behavior, 16, 289-298.

Robinson, S. L., \& Morrison, E. W. (2000). The development of psychological contract breach and violation: A longitudinal study. Journal of Organizational Behavior, 21, 525-546.

Rousseau, D. (1995). Psychological contracts in organizations: Understanding written and unwritten agreements. Thousand Oaks, CA: Sage Publications.

Rousseau, D. (2004). Psychological contracts in the workplace: Understanding the ties that motivate. Academy of Management Executive, 18, 120-127.

Rousseau, D. M., \& Greller, M. M. (1994). Human resource practices: Administrative contract makers. Human resource management, 33, 385-401.

Rupp, D. E., \& Cropanzano, R. (2002). The mediating effects of social exchange relationships in predicting workplace outcomes from multifoci organizational justice. Organizational Behavior and Human Decision Processes, 89, 925-946.

Saks, A. M. (2006). Antecedents and consequences of employee engagement. Journal of Managerial Psychology, 21, 600-619.

Schaufeli, W. B., \& Bakker, A. B. (2004). Job demands, job resources, and their relationship with burnout and engagement: A multi-sample study. Journal of Organizational Behavior, 25, 293-315.

Schaufeli, W. B., Bakker, A. B., \& Salanova, M. (2006). The measurement of work engagement with a short questionnaire. Educational and Psychological Measurement, 66, 701-716.

Shalley, C. E., \& Gilson, L. L. (2004). What leaders need to know: A review of social and contextual factors that can foster or hinder creativity. The Leadership Quarterly, 15, 3353.

Shantz, A., Alfes, K., \& Latham, G. P. (2016). The buffering effect of perceived organizational support on the relationship between work engagement and behavioral outcomes. Human Resource Management, 55, 25-38.

Siemsen, E., Roth, A., \& Oliveira, P. (2010). Common method bias in regression models with linear, quadratic, and interaction effects. Organizational Research Methods, 13, 456-476.

Sijbom, R. B. L., Anseel, F., Crommelinck, M., De Beuckelaer, A., \& De Stobbeleir, K. E. M. (2018). Why seeking feedback from diverse sources may not be sufficient for stimulating creativity: The role of performance dynamism and creative time pressure. Journal of Organizational Behavior, 39, 355-368.

Smither, J. W., London, M., \& Reilly, R. R. (2005). Does performance improve following multisource feedback? A theoretical model, meta-analysis, and review of empirical findings. Personnel Psychology, 58, 33-66. 
Sommer, K. L., \& Kulkarni, M. (2012). Does constructive performance feedback improve citizenship intentions and job satisfaction? The roles of perceived opportunities for advancement, respect, and mood. Human Resource Development Quarterly, 23, 177-201.

Steelman, L. A., Levy, P. E., \& Snell, A. F. (2004). The feedback environment scale: Construct definition, measurement, and validation. Educational and Psychological Measurement, 64, 165-184.

Tabachnick, B. G., \& Fidell, L. S. (2013). Using multivariate statistics (6th ed.). Boston, MA: Pearson

Tekleab, A. G., \& Taylor, M. S. (2003). Aren't there two parties in an employment relationship? Antecedents and consequences of organization-employee agreement on contract obligations and violations. Journal of Organizational Behavior, 24, 585-608.

Tran Huy, P., \& Takahashi, K. (2017). Determinants of psychological contract breach: An empirical study of Vietnamese employees. Management Research Review, 41, 29-45.

Turnley, W. H., Bolino, M. C., Lester, S. W., \& Bloodgood, J. M. (2003). The impact of psychological contract fulfillment on the performance of in-role and organizational citizenship behaviors. Journal of Management, 29, 187-206.

van Wingerden, J., Derks, D., \& Bakker, A. B. (2017). The impact of personal resources and job crafting interventions on work engagement and performance. Human Resource Management, 56, 51-67.

Vigoda-Gadot, E., \& Angert, L. (2007). Goal setting theory, job feedback, and OCB: Lessons from a longitudinal study. Basic and Applied Social Psychology, 29, 119-128.

Wang, X. (2012), China's civil service reform. London: Routledge.

Wang, X. H., Fang, Y., Qureshi, I., \& Janssen, O. (2015). Understanding employee innovative behavior: Integrating the social network and leader-member exchange perspectives. Journal of Organizational Behavior, 36, 403-420.

West, M. A. (2002). Sparkling fountains or stagnant ponds: An integrative model of creativity and innovation implementation in work groups, Applied Psychology, 51, 355-387.

Whitaker, B. G., Dahling, J. J., \& Levy, P. (2007). The development of a feedback environment and role clarity model of job performance. Journal of Management, 33, 570-591.

Wu, J., Ma, L., \& Yang, Y. (2013). Innovation in the Chinese public sector: Typology and distribution. Public Administration, 91, 347-363.

Xanthopoulou, D., Bakker, A. B., Demerouti, E., \& Schaufeli, W. B. (2009). Reciprocal relationships between job resources, personal resources, and work engagement. Journal of Vocational Behavior, 74, 235-244.

Zhao, H., Wayne, S. J., Glibkowski, B. C., \& Bravo, J. (2007). The impact of psychological contract breach on work-related outcomes: A meta-analysis. Personnel Psychology, 60, 647-680.

Zheng, X., Diaz, I., Jing, Y., \& Chiaburu, D. S. (2015). Positive and negative supervisor developmental feedback and task-performance. Leadership \& Organization Development Journal, 36, 212-232.

Zhou, J. (2003). When the presence of creative coworkers is related to creativity: Role of supervisor close monitoring, developmental feedback, and creative personality. Journal of Applied Psychology, 88, 413-422.

Zhou, J., \& George, J. M. (2001). When job dissatisfaction leads to creativity: Encouraging the expression of voice. Academy of Management Journal, 44, 682-696.

Zhou, Y., Hong, Y, \& Liu, J. (2013). Internal commitment or external collaboration? The impact of human resource management systems on firm innovation and performance, Human Resource Management, 52, 263-288. 
Table 1: Means, standard deviations, reliabilities and correlations among the study variables

\begin{tabular}{|c|c|c|c|c|c|c|c|c|c|c|c|c|c|}
\hline \multicolumn{2}{|c|}{ Variable } & $M$ & $S D$ & 1 & 2 & 3 & 4 & 5 & 6 & 7 & 8 & 9 & 10 \\
\hline 1 & $\mathrm{Age}^{\mathrm{a}}$ & 34.02 & 5.75 & - & & & & & & & & & \\
\hline 2 & Gender ${ }^{b}$ & 1.53 & 0.50 & .02 & - & & & & & & & & \\
\hline 3 & Education $^{c}$ & 2.31 & 1.23 & -.07 & -.01 & - & & & & & & & \\
\hline 4 & Tenure under the supervisor ${ }^{a}$ & 3.84 & 2.47 & .54 & -.10 & -.07 & - & & & & & & \\
\hline 5 & Organizational tenure $^{\mathrm{a}}$ & 5.91 & 3.39 & .60 & -.10 & -.07 & $.78 * *$ & - & & & & & \\
\hline 6 & Supervisor feedback & 3.99 & 0.76 & -.01 & -.05 & -.02 & .02 & .04 & $(.87)$ & & & & \\
\hline 7 & Co-worker feedback & 3.99 & 0.76 & .04 & -.04 & .04 & $.12 *$ & .11 & $.41 * *$ & $(.88)$ & & & \\
\hline 8 & Work engagement & 4.04 & 0.77 & -.04 & -.03 & .05 & .03 & -.01 & $.23 * *$ & $.24 * *$ & $(.90)$ & & \\
\hline 9 & Psychological contract breach & 2.19 & 0.82 & .05 & .03 & .03 & $-.17 * *$ & -.11 & $-.41 * *$ & $-.41 * *$ & $-.43 * *$ & $(.91)$ & \\
\hline 10 & Innovative behavior & 3.77 & 0.79 & -.06 & -.07 & .05 & .03 & -.05 & $.18^{* *}$ & $.18^{* *}$ & $.28 * *$ & $-.29 * *$ & $(.89)$ \\
\hline
\end{tabular}

Number of Employees $=300 ;$ Number of Supervisors $=64$.

$p<.05,{ }^{* *} p<.01$. Cronbach's alpha coefficients on the diagonal.

${ }^{a}$ Employee age, tenure under the supervisor and tenure working for the organization were all measured as continuous variables (i.e. number of years).

${ }^{\mathrm{b}}$ Gender coded: 1 = male; 2 = female.

'Employee education coded: 1 = high school, $2=$ undergraduate, $3=$ master's degree, $4=\mathrm{PhD}$. 
TABLE 2: Results of confirmatory factor analysis

\begin{tabular}{|c|c|c|c|c|c|c|}
\hline Model & $x^{2}$ & $d f$ & RMSEA & 90\% CI RMSEA & CFI & TLI \\
\hline Hypothesized five-factor model & 527.42 & 289 & .052 & $.045-.059$ & .971 & .967 \\
\hline $\begin{array}{l}\text { Four-factor model: Supervisor feedback and co-worker feedback } \\
\text { combined }\end{array}$ & 736.976 & 293 & .071 & $.065-.077$ & .945 & .939 \\
\hline $\begin{array}{l}\text { Four-factor model: Work engagement and psychological contract } \\
\text { breach combined }\end{array}$ & 1403.882 & 293 & .112 & $.107-.118$ & .863 & .848 \\
\hline $\begin{array}{l}\text { Three-factor model: Supervisor feedback and co-worker feedback } \\
\text { combined, and work engagement and psychological contract breach } \\
\text { combined }\end{array}$ & 1528.296 & 296 & .118 & $.112-.124$ & .848 & .833 \\
\hline $\begin{array}{l}\text { Two-factor model: Supervisor feedback, co-worker feedback, work } \\
\text { engagement, and psychological contract breach combined }\end{array}$ & 2579.361 & 298 & .160 & $.154-.165$ & .719 & .694 \\
\hline $\begin{array}{l}\text { Two-factor model: Supervisor feedback and co-worker feedback } \\
\text { combined and work engagement, psychological contract breach, and } \\
\text { innovative behavior combined }\end{array}$ & 2590.689 & 298 & .160 & $.154-.166$ & .718 & .692 \\
\hline One-factor model & 3799.230 & 299 & .198 & $.192-.203$ & .569 & .532 \\
\hline
\end{tabular}

Notes: All alternative models were compared to the five-factor model. RMSEA = Root Mean Square Error of Approximation; CFI = Comparative Fit Index; TLI = Tucker-Lewis Index 
Table 3: Results of the mediation analysis

\begin{tabular}{|c|c|c|c|}
\hline & \multicolumn{2}{|c|}{$\mathrm{X} \rightarrow \mathrm{Y}$} & \multirow{2}{*}{$\begin{array}{c}\mathrm{X} \rightarrow \mathrm{M} \rightarrow \mathrm{Y} \\
\text { Innovative Behavior }\end{array}$} \\
\hline & Work Engagement & Psychological Contact Breach & \\
\hline Age & -.04 & $.19^{*}$ & -.01 \\
\hline Gender & -.01 & -.01 & -.06 \\
\hline Education & .05 & .02 & .04 \\
\hline Tenure under the supervisor & .10 & $-.25 * *$ & .10 \\
\hline Organizational tenure & -.06 & -.01 & -.14 \\
\hline Supervisor feedback & $.23^{*}$ & $-.29 * *$ & -.04 \\
\hline Work engagement & & & $.18^{*}$ \\
\hline Psychological contact breach & & & $-.22 *$ \\
\hline \multicolumn{4}{|l|}{ Bootstrapping indirect effects } \\
\hline Supervisor feedback $\rightarrow$ work engagement & & & $.04(95 \%$ CI .01 .10) \\
\hline Supervisor feedback $\rightarrow$ psychological contract breach & & & $.06(95 \%$ CI .02 .11) \\
\hline$R^{2}$ & .06 & .14 & .10 \\
\hline
\end{tabular}


Table 4: Results of the moderated-mediation analysis

\begin{tabular}{|c|c|c|c|}
\hline & \multicolumn{2}{|c|}{$X \rightarrow Y$} & \multirow{2}{*}{$\begin{array}{c}\mathrm{X} \rightarrow \mathrm{M} \rightarrow \mathrm{Y} \\
\text { Innovative Behavior }\end{array}$} \\
\hline & Work Engagement & Psychological Contact Breach & \\
\hline Age & -.05 & $.19^{*}$ & -.01 \\
\hline Gender & -.01 & -.01 & -.06 \\
\hline Education & .04 & .03 & .04 \\
\hline Tenure under the supervisor & .07 & $-.21 * *$ & .10 \\
\hline Organizational tenure & -.06 & -.01 & -.14 \\
\hline Supervisor feedback & $.16^{*}$ & $-.16^{* *}$ & -.04 \\
\hline Co-worker feedback & .10 & $-.28 * *$ & - \\
\hline Supervisor feedback $*$ Co-worker feedback & $-.19 *$ & $.14 * *$ & - \\
\hline Work engagement & & & $.18^{*}$ \\
\hline Psychological contact breach & & & $-.22 *$ \\
\hline$R^{2}$ & .12 & .24 & .11 \\
\hline
\end{tabular}


Table 5: Conditional indirect effects of moderated-mediation analyses

\begin{tabular}{|c|c|c|c|}
\hline & Indirect effects & S.E. & $95 \%$ Confidence Intervals \\
\hline \multicolumn{4}{|c|}{ Supervisor Feedback $\rightarrow$ Work Engagement $\rightarrow$ Innovative Behavior } \\
\hline$-1 S D$ below the mean & .06 & .03 & $.01-.15$ \\
\hline Mean & .03 & .02 & $.01-.07$ \\
\hline$+1 S D$ above the mean & -.01 & .01 & $-.04-.02$ \\
\hline \multicolumn{4}{|c|}{ Supervisor Feedback $\rightarrow$ Psychological Contact Breach $\rightarrow$ Innovative Behavior } \\
\hline$-1 S D$ below the mean & .06 & .02 & $.03-.11$ \\
\hline Mean & .03 & .02 & $.01-.06$ \\
\hline$+1 S D$ above the mean & .01 & .01 & $-.02-.03$ \\
\hline
\end{tabular}


Figure 1: Hypothesized Model

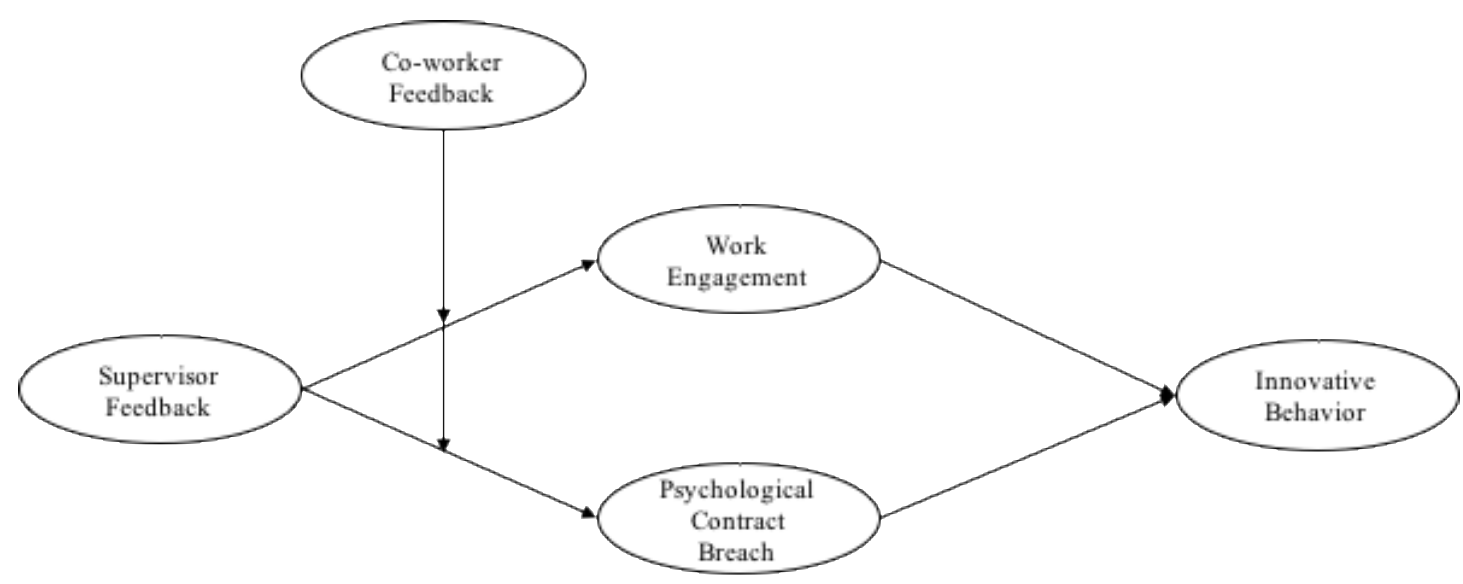


Figure 2: Interaction between supervisor feedback and co-worker feedback on work engagement

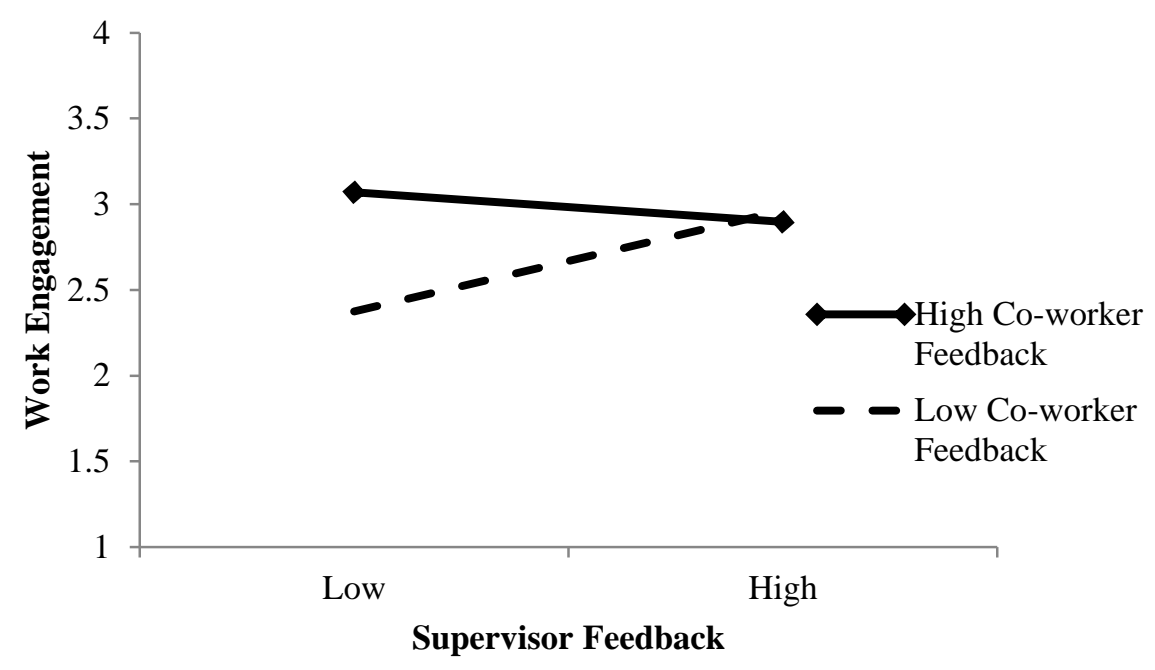


Figure 3: Interaction between supervisor feedback and co-worker feedback on psychological contract breach

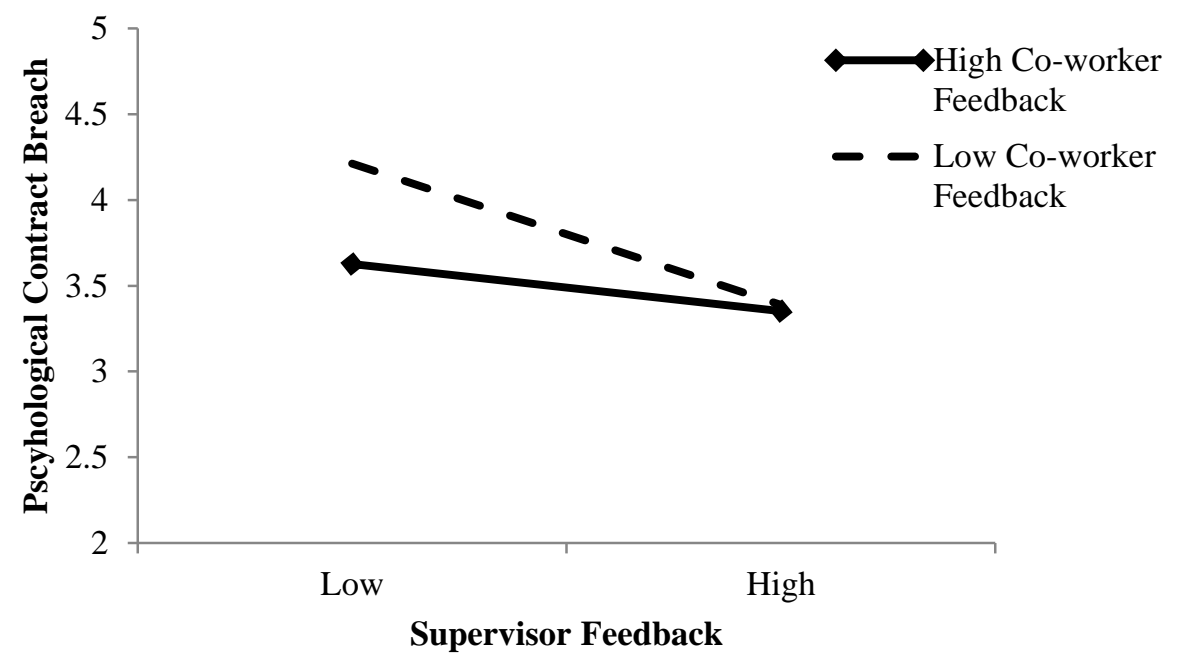

